\title{
O potrzebie pisania wprowadzeń, czyli o klasycyzmie po chorwacku
}

\section{Cvijeta Pavlović, Uvod u klasicizam, Leykam International, Zagreb 2012, 308 s.}

Książkę Cvijety Pavlović Uvod u klasicizam (Wstęp do klasycyzmu) można sytuować w segmencie naukowej propedeutyki użytecznej, jeśli brać pod uwagę założenia i przewidywane funkcje oraz docelowe czy też potencjalnie pozyskane grono adresatów. Publikacja wpisuje się w szeroki i popularny nurt ogólnych wprowadzeń do zagadnień fundamentalnych dla rozwoju kultury i literatury europejskiej, jest syntetycznym omówieniem klasycyzmu oraz przeglądem jego najważniejszych literackich realizacji na poszczególnych (narodowych) obszarach Europy. Wypada stwierdzić również, że pozycja ta nosi dość wymowny, a wręcz sugestywny tytuł, który zainteresowanego czytelnika niemalże natychmiast kieruje w sferę schematycznych przypuszczeń i utartych oczekiwań. Przed lekturą tego niewielkiego rozmiaru (w sensie wydawniczym: kieszonkowego) opracowania nasuwają się podstawowe pytania o sens jego pojawienia się w obiegu czytelniczym, o jego cel i przeznaczenie, o to, czy wciąż jeszcze istnieje zapotrzebowanie na zwięzłe prezentacje tematów ważkich, które wydają się już po wielekroć i kompleksowo omówione.

W tym przypadku jednak pewne wątpliwości i obawy stosunkowo szybko ustępują, bo już w przedmowie do rozprawy autorka podkreśla, że tego typu tematyczne opracowanie nie zostało dotychczas opublikowane w języku chorwackim. Co więcej, twierdzi, że nadrzędnym zamierzeniem i swoistym uzasadnieniem powstania publikacji jest syntetyczne ujęcie i powiązanie wielu terminów, nazwisk twórców i tytułów dzieł, które jej zdaniem na niewielu stronach i w bezpośredni sposób mogłyby trafić do jak najszerszego grona czytelników, zarówno znawców problematyki, jak i odbiorców spoza specjalistycznych kręgów. Wprawdzie pod względem 
popularyzatorskim taka wyeksplikowana wprost motywacja całkowicie i naturalnie znajduje rację bytu, wciąż jednak otwarta pozostaje kwestia naukowej wartości, faktycznego znaczenia i przełożenia tego rodzaju przeglądowych studiów w kontekście choćby profesjonalnego zastosowania.

Jeśli upatrywać dla rozprawy Cvijety Pavlović miejsca w konkretnym dziale naukowej aktywności, to należy ją zaliczać do tradycyjnego nurtu komparatystyki literackiej. Książka ma zwartą i spójną strukturę, którą tworzą trzy obszary rozważań, komplementarne bloki zagadnień osadzone w porządku starannie przemyślanej chronologii narracyjnej. Trójdzielny układ prezentacji czyni wywód logicznym i jasnym. Autorka opisuje fenomen klasycyzmu, rozpoczynając od ustaleń terminologicznych, przywołania i zestawienia najważniejszych pojęć i pól semantycznych, dalej dokonuje przeglądu klasycystycznych realizacji w przestrzeni narodowych literatur, a kończy na ekspozycji wspólnych dla tradycji klasycystycznej form i treści, wskazując także nowe możliwości interpretacyjne i ścieżki badawcze.

Pierwsza część, na którą składa się ustęp pod tytułem Nazivlje - klasika, klasicizam, neoklasicizam (Terminologia - klasyka, klasycyzm, neoklasycyzm), została poświęcona podstawowym ustaleniom i zakresom kategorialnym, kluczowym definicjom klasyczności, klasycyzmu i neoklasycyzmu, motywem przewodnim jest tu uściślenie, a jednocześnie rozgraniczenie terminów, przede wszystkim zaś doprecyzowanie przedmiotowego pojęcia z uwzględnieniem wymiaru jego czasoprzestrzennej zmienności czy też znaczeniowej płynności i pluralizmu. Podjęcie problemu dookreślenia samej nazwy jest tym bardziej uzasadnione, że ta nadal występuje jako niejednoznaczna, co powoduje wiele trudności w oglądzie samej epoki, niejednokrotnie wywołując gorące dyskusje w kręgu literaturoznawców, szczególnie zaś w prowadzonych badaniach o profilu porównawczym.

W podrozdziale Klasicizam i racionalizam (Klasycyzm i racjonalizm) podnoszącym problem odniesień klasycyzmu i racjonalizmu nakreślone zostało tło filozoficzne i kulturowe oraz wyeksponowane idee, które miały istotny wpływ na ukształtowanie omawianego fenomenu; wyróżnione zostały główne programy umysłowe i ich przedstawiciele, m.in. Descartes, Pascal, Hobbes, Locke, Spinoza, Newton, Leibniz.

W dalszej części zatytułowanej Poetika klasicizma (Poetyka klasycyzmu) autorka omówiła regułę organizacyjną klasycyzmu, ujawniając 
jego specyficzny i trwały wzór, zwróciła też uwagę na założenia formalne, przede wszystkim zaś na charakterystyczne i dominujące gatunki literackie.

Teoretyczno-rekapitulacyjna refleksja została osadzona w szerszym kontekście historycznoliterackim, opatrzona wnioskami na temat kontynuacji i odrębności klasycyzmu wobec teorii i koncepcji poprzednich epok - renesansu i baroku, co autorka uczyniła w podrozdziale Novovjeke prethodnice klasicizma (Nowożytni poprzednicy klasycyzmu). Warto podkreślić, że tym rozważaniom nieustannie i wyraźnie towarzyszyło dążenie do precyzyjniejszego niż dotychczas w nauce określenia wyznaczników zarówno formalnych, jak i temporalnych opisywanego zjawiska.

Drugi i najważniejszy segment książki, zatytułowany Klasicizam u nacionalnim književnostima (Klasycyzm w literaturach narodowych), stanowi syntetyczny przegląd literackich ucieleśnień szeroko i różnorodnie pojmowanego programu klasycystycznego. Autorka uwydatniła duże zróżnicowanie czasowe i reprezentacyjne zjawiska przez wskazanie na jego rozmaite warianty w poszczególnych literaturach - francuskiej, angielskiej, włoskiej, niemieckiej, polskiej, rosyjskiej, chorwackiej, węgierskiej, hiszpańskiej, portugalskiej, duńskiej, holenderskiej, serbskiej, czeskiej, słowackiej i ukraińskiej. Swoistą osią tego zarysu stał się wyznacznik uniwersalności i lokalności klasycystycznych realizacji, stałości i zmienności tego samego wzorca w różnych przestrzeniach literackich, co autorka udowodniła na przykładzie konkretnych autorów i ich dzieł. Ta część rozprawy stanowi nie tylko katalog reprezentatywnych dla epoki kompozycji, ale jest także autorską, choć szkicową, analizą problemu adaptacji, implementacji i funkcjonowania prymarnego paradygmatu w określonych warunkach kulturowych, próbą nakreślenia rodzimego, to jest właściwego dla kolejno omawianych narodowych obszarów, tła jego urzeczywistnienia. Analiza i interpretacja narodowych korpusów literackich została $\mathrm{z}$ jednej strony podporządkowana strategii ujawnienia i wykazania funkcjonalności wspólnego modelu, z drugiej zaś poddana taktyce prezentowania odrębności, wielowymiarowości w sferze realizacyjnej. Warto podkreślić, że o ile sporo uwagi Cvijeta Pavlović poświęciła tzw. wielkim literaturom europejskim - francuskiej, angielskiej, włoskiej i niemieckiej, prezentując sztandarowe przykłady klasycystycznych realizacji i ich tło kulturowe, o tyle pozostałe narodowe obszary zostały przez nią 
potraktowane znacznie oszczędniej. W tym zakresie pewnym wyjątkiem jest macierzysta dla autorki literatura chorwacka, która w swej klasycystycznej fazie została nieco szerzej przedstawiona, bo przykładowo oprócz tekstów Katančicia czy tzw. chorwackich latynistów, przywołana została również twórczość luźniej nawiązująca do opisywanego programu: Frankopana, Relkovicia, Dražicia, Kunicia, Zamanji i innych. Pomimo nieproporcjonalnej skali przywołań, należy stwierdzić, że całość tworzy w miarę spójny, nawet jeśli miejscami dość powierzchowny, zarys wielorakich projekcji czy manifestacji jednego - a jakże przez to niejednoznacznego modelu. Taka forma prezentacji wydaje się wartościowa również ze względu na swą syntetyczność, pozostawiając i nie zagłębiając się już w kwestię stopnia rozwinięcia pojedynczego wątku czy też większego problemu.

Ostatni dział książki pod tytułem Književni oblici i sadržaji u klasicizmu i Klasicizam nakon klasicizma (Literackie formy i treści w klasycyzmie i Klasycyzm po klasycyzmie) nie przypomina tradycyjnego podsumowania, w rzeczywistości jest swoistym otwarciem i nakreśleniem kierunków oraz wyzwań, które wciąż stoją przed badaczami odnośnie do refleksji nad klasycyzmem w Europie, stanowi również zwarty opis charakterystycznych dlań form i gatunków. Autorka wyróżnia tu epos, tragedię, poemat dydaktyczny, odę, epistołę, bajkę, satyrę, elegię i komedię, uwypuklając przy tym obowiązującą wówczas zasadę czystości gatunkowej i stylistycznej, która, jak wiadomo, w przyszłości okazała się przedmiotem sporu pomiędzy artystycznymi generacjami. W tej części znalazły się też krótkie przemyślenia na temat żywotności klasycyzmu czy też jego przeobrażenia w nową jakość, co należy pojmować w aspekcie tzw. długiego trwania wzorca.

W narracji autorka konsekwentnie podejmowała trud precyzyjnego zdefiniowania pojęcia klasycyzmu, uchwycenia jego periodyzacyjnych granic, rekonstrukcji i interpretacji zjawiska jako całości przy założeniu jego niejednorodności i wysokiej dynamiki. O wartości jej książki decyduje również fakt, że jest to, jak wspomniano, pierwsze w języku chorwackim komparatystyczne opracowanie na temat fenomenu klasycyzmu na szerokim tle historycznym, kulturowym i narodowym, które może służyć zarówno celom popularyzatorskim, jak i badawczym w perspektywie kolejnych naukowych projektów obszerniej już podnoszących ten temat. Warto podkreślić, że rozprawa ta ma niebagatelne znaczenie zarówno dla 
chorwackiego, jak i slawistycznego literaturoznawstwa, bo w pewien sposób wynosi z obszaru marginalnego twórczość wielu słowiańskich literatur o charakterze klasycystycznym, stawiając ją na pozycji równoprawnej z dziedzictwem innych epok. Należy wprost powiedzieć, że dotąd wśród licznych przykładów nie został jasno wyodrębniony korpus tekstów, które można by określić mianem jednoznacznie klasycystycznych.

Wszystko to powoduje, że wbrew pierwotnym obawom i postawionym na początku pytaniom o sens i potrzebę powstawania tak ogólnych, syntetycznych wprowadzeń $\mathrm{w}$ zagadnienia fundamentalne, w tym przypadku bezspornie mamy do czynienia nie tylko z tradycyjnym wstępem do danej problematyki, ale też z dojrzałym koncepcyjnym studium, które można traktować jako swego rodzaju punkt wyjścia do dalszych rozważań. Książkę Cvijety Pavlović należy uznać za inspirującą lekturę i za wartościową podstawę, korzystną w sferze akademickiej dydaktyki oraz badań naukowych, przede wszystkim zaś trzeba w niej widzieć publikację stanowiącą ważny głos w dyskusji nad zagadnieniami pozornie już opracowanymi, a jednak, jak się okazuje, wciąż wymagającymi dalszej pogłębionej czy wręcz o wiele bardziej precyzyjnej refleksji w omawianym zakresie. 